\title{
Eulalia Carrasco A. H.P., 2010, Los Épera Siapidara en Ecuador. De la invisibilidad a la visibilidad.
}

$\mathrm{S}$ ucedió en una inmensa playa a orillas del río Chocó. No había gente, solo cielo, mar y selva. La madre Tachi Ñawe bajó con su hijo Tachi Ak'ore para vivir en la playa solitaria. El niño buscaba salir de esa soledad, por lo que dijo a Tachi Nawe: "mamá, me siento solo, voy a hacer un pueblo". Recogió, entonces, diversos materiales y modeló muñecos: de los de barro nacieron varios pueblos, de los de chonta se hicieron los negros, de los muñecos de caña brava se formaron los Épera. A todos los figurines les enterró en el arenal. A media noche les gritó: “¡mis hijos, levántense, ustedes se volverán personas como yo!” De inmediato, todas las gentes se levantaron alegres, gritando como en una fiesta. Disgustado porque escuchó a todos con una sola habla, ordenó que cada pueblo tuviera su propio idioma: a los gringos les dio su lengua, a cada grupo indígena la suya propia, y a los Épera les otorgó su idioma; por eso cada uno tiene su rezo y "Tachi Ak'ore entiende a cada uno en su idioma".

Los mitos de los Épera forman al "Pueblo indígena originario de la caña brava", explica la antropóloga graduada en la PUCE, Eulalia Carrasco Andrade H.P., por lo que, con una identidad definida, fundamentan sus formas de vida y justifican, una vez más, la pluriculturalidad y el multilingüismo de nuestros países. Por haber sido creados por Tachi Ak'ore a la vera del Chocó, su tarea es peregrinar, como fluyen las aguas del río. Han respondido a este mandato con estrategias creativas frente a sus vecinos. Los Épera Siapidara, como parte de la familia Emberá, son originarios de la región del Chocó (Panamá y Colombia). Los radicados en el Ecuador proceden, mayoritariamente, de los asentamientos situados junto a los ríos Infi, Micay y Saija (Calle Santa Rosa), en el departamento del Cauca, Colombia. Desde hace medio siglo, por los acontecimientos socio-políticos de Colombia se vieron obligados a emigrar a la provincia de Esmeraldas, en el Ecuador, y se dispersaron por las orillas de los ríos, desde Limones hasta Quinindé, asentándose como peones en las fincas de los afrodescendientes de la zona, y manteniéndose invisibles, bajo el apodo denigrante de "cholos colombianos" o "chocoes". Actualmente, después de un largo recorrido, el grupo indígena ecuatoriano Épera, compuesto por unas 80 familias nucleares con una población de 400 personas, se ha ubicado en el pueblo recién fundado de Santa Rosa de los Épera, a orillas del río Cayapas.

Los desplazamientos forzosos, el temor ante el acoso de grupos armados, el rechazo por su condición de "indocumentados", exigieron al "pueblo originario de la caña brava" una estrategia de "invisibilización" y una presencia anónima en situación de servidumbre y explotación. 
Asesorado por una religiosa antropóloga y apoyado por varias instituciones, el pueblo Épera ecuatoriano ha superado la invisibilidad para asumir su identidad y destino: familias dispersas, ocultas por décadas, se han constituido en un pueblo asentado en un pequeño territorio, con organización comunitaria frente al Estado, a las ONGs y a la sociedad civil.

En su libro "Los Épera Siapidara en Ecuador. De la invisibilidad a la visibilidad", Eulalia Carrasco nos ofrece un testimonio bilingüe, en castellano y en siapedee, al modo de una verdadera "historia clínica", como un diagnóstico social y previsiones de "otro horizonte" para este pueblo indio. Esta obra no es una etnografía, en el sentido clásico, que pretende ofrecer la "visión objetiva" del investigador; es más bien el mutuo testimonio de un pueblo que descubre su identidad oculta, gracias a la labor de una antropóloga humanista que ha encontrado en esta tarea su misión cristiana. No admira, por lo tanto, que inicie su obra, en la primera parte, con la exposición de las raíces hondas de la cultura del pueblo Épera, rizomas que le posibilitaron mantener su identidad en situaciones adversas y retomar el camino de "ser pueblo". En la segunda parte se describen las etapas de migración hacia el Ecuador y su dispersión a lo largo de la provincia de Esmeraldas. No se deja de lado, en la tercera parte, el proceso de organización socio-política que busca recuperar las normas de justicia ancestrales y el camino recorrido para la adquisición y posesión de un territorio. Finalmente, se busca explicar la "invisibilización" impuesta por los conflictos armados y por los intereses de los finqueros: invisibilización que continúa, como consecuencia de la globalización, en la vida de los Épera y que exige un proceso constante para superarla. "La convivencia de cinco años (1999-2004) con el Pueblo Épera, desde los asentamientos en los ríos, hasta el territorio y la legalización de la organización, siendo partícipe en las fiestas, en las danzas, en las luchas, en las violencias internas y externas, -confiesa la autora- ahondó las exigencias espirituales, éticas, intelectuales, relacionales para encontrar comunitariamente soluciones frente a las injusticias, al sufrimiento de la invisibilización, que es una forma de genocidio. La urgencia de territorio, producción, salud, educación era y sigue siendo fundamental" (Carrasco, 2010:6-7).

Aunque en la obra se privilegia una visión optimista, Eulalia Carrasco no olvida señalar los difíciles retos futuros. Quizás el más severo es el problema demográfico, ya que la tradición exige endogamia étnica en la elección de la pareja, mezclada con la obligación de no casarse entre parientes hasta la cuarta generación. Esta exigencia no puede ser acatada por las familias asentadas en el Ecuador, por lo que, cada vez, son más numerosas las uniones conyugales con la población afroesmeraldeña, lo que significa aceptar un proceso de aculturación y un profundo cambio de valores. Parecida es la situación en el acceso a la propiedad comunal, pues una parte de las 320 hectáreas del "territorio" perteneciente al asentamiento de Santa Rosa de los Épera ya ha sido tomada, abusivamente, por algunos indígenas épera y vendida a propietarios extraños. En su forma de vida, se nota además la transformación económica hacia el comercio de cacao, la elaboración de artesanías (cestería, etc.) para su venta a los turistas, etc., todo lo cual significará el ingreso necesario en otro modelo económico. No está ausente, desgraciadamente, el temor a la expansión de la violencia por la guerrilla y el narcotráfico. Estos y otros retos exigen a los antropólogos y gestores sociales que en el futuro se comprometan a seguir los pasos de Eulalia Carrasco, a abandonar un ingenuo ancestralismo cultural y a practicar una permanente "investigación-acción", que posibilite un acompañamiento respetuoso en la búsqueda de soluciones autogestionadas frente a los desafíos futuros. 